\title{
MENDAYAGUNAKAN PERAN KARANG TARUNA DALAM IMPLEMENTASI BAKTI SOSIAL MEMBANTU MENGURANGI BEBAN EKONOMI MASYARAKAT AKIBAT WABAH GLOBAL COVID-19 DI LINGKUNGAN RW 011 KELURAHAN PENGASINAN KOTA DEPOK
}

\author{
Dira Karlina, Agus, Paeno, Ryan Elfahmi \\ Universitas Pamulang \\ Email: dosen01553@unpam.ac.id
}

\begin{abstract}
At this Community Servise (PKM) took the object of research, namely Youth Organization and Residents of RW 011 Pengasinan Urban Village, Depok City. The purpose of this PKM activity is to help some of the people who are directly affected by the Covid-19 pandemic, so that they have better resilience in dealing with this Covid-19 pandemic. This PKM activity is carried out by providing material assistance in social, moral and knowledge services to build a positive mindset that can strengthen their endurance materially and morally and help them to think more critically and creatively to create new opportunities that are useful for increasing their strength. their economy. The results of this PKM activity were the distribution of a number of material assistance and increased motivation from members of the Youth Organization and local residents to continue to struggle to bring up critical thoughts that gave birth to creative ideas in responding to the Covid-19 pandmei, so as to increase community resilience to get out of economic pressure due to covid-19.
\end{abstract}

Keywords: Youth Organization, Social Service, Economic Pressure, Covid19.

\begin{abstract}
Abstrak
Pengabdian Kepada Masyarakat ini mengambil objek penelitian yaitu Karang Taruna dan Warga RW 011 Kelurahan Pengasinan Kota Depok. Tujuan dari kegiatan PKM ini adalah untuk membantu sebagian masyarakat yang terdampak langsung pandemi covid-19 agar memiliki daya tahan lebih baik dalam menghadapi pendemi covid-19 ini. Kegiatan PKM ini dilakukan dengan memberikan bantuan materil dalam bakti sosial, moril dan pengetahuan untuk membangun pola pikir positif yang dapat memperkuat daya tahan mereka secara materi dan moril, serta membantu mereka untuk berpikir lebih kritis dan kreatif untuk menciptakan peluang-peluang baru yang berguna untuk meningkatkan kekuatan ekonomi mereka. Hasil dari kegiatan PKM ini yaitu tersalurkannya sejumlah bantuan materiil dan meningkatnya motivasi dari anggota Karang Taruna dan warga setempat untuk terus berjuang memunculkan pemikiran-pemikiran kritis yang melahirkan ide-ide kreatif dalam menyikapi pandemi covid-19, sehingga
\end{abstract}


dapat meningkatkan daya tahan masyarakat agar keluar dari tekanan ekonomi akibat covid-19 ini.

Kata Kunci: Karang Taruna, Bakti sosial, Tekanan Ekonomi, Covid-19.

\section{A. PENDAHULUAN}

Hampir seluruh negara di dunia telah melaporkan adanya kasus covid-19 di negaranya, termasuk Indonesia. Perkembangan jumlah kasus baru (positif) yang terkena covid-19 dan kasus kematian masih mengalami peningkatan setiap harinya, termasuk jumlah yang sembuh juga meningkat. Pada tanggal 16 Agustus'20, di Indonesia kasus covid-19 yang sudah terkonfirmasi positif ada 139.549 orang, sembuh 93.103 dan meninggal 6.150. Pandemi covid-19 telah berdampak pada semua aspek kehidupan, termasuk aspek ekonomi dan pendidikan.

Sedangkan di Provinsi Jawa Barat, per tanggal 16 Agustus'20, yang terkonfirmasi positif sejumlah 8.595 orang, sembuh 4.668 dan meninggal 237. Untuk kota Depok, per tanggal 13Agustus'20, jumlah kasus positif ada 1.575 orang, sembuh 1.138 dan meninggal 56 orang. Depok termasuk kota di Jawa Barat yang masih tinggi kasus covid-19 nya. Kasus covid-19 hampir merata ditemukan di seluruh kelurahan di Kota Depok. Berdasarkan data dari Pusat Informasi Covid-19 kota Depok, per tanggal 9 Mei 2020, 59 dari 63 kelurahan di Kota Depok memiliki kasus positif corona. Sehingga, ada 4 kelurahan di Kota Depok yang belum memiliki atau terbebas kasus positif corona, yaitu Kelurahan Leuwinanggung, Kelurahan Pengasinan, Kelurahan Bojong Pondok Terong dan Kelurahan Gandul. Karena adanya aktivitas sosial yang dibatasi dalam rangka mengurangi penyebaran covid-19, maka aktivitas ekonomi tersendat juga, sehingga penghasilan masyarakat setempat menjadi berkurang atau bahkan ada yang kehilangan penghasilannya.

Karang Taruna merupakan wadah pengembangan generasi muda,yang tumbuh atas dasar kesadaran dan rasa tanggung jawab sosial dari, oleh dan untuk masyarakat, khususnya generasi muda di wilayah desa/ kelurahan atas komunitas sosial derajat, yang terutama bergerak di bidang kesejahteraan sosial. Karang Taruna bisa memberikan kontribusi dalam berbagai upaya mengelola dan menangani masalah sosial seperti bencana alam dan bencana sosial.

Karang Taruna sebagai pilar sosial dianggap mengenal daerah masing-masing, ini merupakan kunci utama dari penanganan covid-19. Di lain pihak, sebagian dari anggota Karang Taruna tersebut merupakan pendamping untuk menerima manfaat dalam kegiatan ini. Namun tetap saja, pandemi covid-19, merupakan hal baru dimana para anggota Karang Taruna juga merasakan dampaknya, sehingga perlu pengarahan dan pendampingan dari pihak-pihak yang mengerti cara menangani situasi ini, disesuaikan dengan program pemerintah. Karang Taruna bisa membantu menggugah kesadaran masyarakat agar taat pada anjuran pemerintah untuk tetap di rumah saja dan melaksanakan protokol kesehatan.

Dengan keberadaan Karang Taruna seperti diatas, maka pemuda Karang Taruna Kelurahan Pengasinan harus dapat dilibatkan dalam upaya penanganan Covid-19, dengan lingkungan yang paling kecil yaitu Kelurahan Pengasinan RW 011. Tujuan dasar pada saat terbentuknya Karang Taruna RW 011 adalah agar Karang Taruna sebagai wadah generasi muda dapat bermanfaat dan membantu program pemerintah untuk kesejahteraan masyarakat sekitar. 
Latar belakang diadakannya kegiatan PKM ini karena sebagian masyarakat sudah dalam kondisi ekonomi yang sangat memprihatinkan, adanya semangat yang menurun dari masyarakat dalam menangani covid-19 secara bersama-sama, dan keterbatasan sebagian masyarakat dalam mengembangkan ide dan kreativitasnya untuk meminimalisir dampak pandemi covid-19. Tujuan dari kegiatan PKM ini adalah bersama Karang Taruna meningkatkan kesadaran masyarakat setempat untuk mengikuti dengan disiplin tinggi program pemerintah dalam memutus mata rantai penyebaran virus covid-19, membantu masyarakat yang sudah mengalami kondisi ekonomi yang sulit serta meningkatkan kekuatan moril masyarakat disaat adanya covid-19 ini.

\section{B. METODE PELAKSANAAN KEGIATAN}

Metode kegiatan yang digunakan adalah melakukan survey awal, pemantapan dan penentuan lokasi dan sasaran, kemudian bekerjasama dengan Karang Taruna RW 011 , Kel. Pengasinan Kota Depok untuk memberikan motivasi kepada warga setempat terkait dengan penanganan kasus pandemi covid-19 melalui cara-cara berikut :

1. Pendampingan

Membuka mindset tentang pentingnya Karang Taruna sebagai wadah untuk mencetak pemuda yang madani dan kreatif, mampu memberikan manfaat kepada masyarakat melalui peranannya menjadi pilar-pilar kesejahteraan sosial, menjadi mitra kerja pemerintah.

2. Penyuluhan

Penyuluhan yang dilakukan adalah sebagai berikut :

a. Mengenai sumber wabah virus covid-19 yang berasal dari Kota Wuhan di China, dimana saat ini tingkat kematian akibat virus tersebut sudah cukup meningkat di seluruh dunia.

b. Langkah-lamngkah yang perlu dilakukan untuk waspada terhadap penyebaran virus tersebut, dimulai dari pertanyaan mengenai perjalanan ke negara-negara yang terjangkit virus covid-19.

c. Tindakan 3M (mencuci tangan, memakai masker dan menjaga jarak) yang harus selalu dilakukan, yaitu mencuci tangan sesering mungkin setelah beraktifitas dengan menggunakan sabun atau handsanitizer, menggunakan selalu masker jika berada di luar rumah (ada slogan maskerku melindungimu dan maskermu melindungiku) dan menjaga jarak dengan orang lain sekitar 1 meter jika sedang berdekatan. Jika sakit flu, batuk yang disertai demam agar segera memeriksakan diri ke dokter.

d. Memberikan contoh-contoh kasus yang memotivasi masyarakat untuk terus bertahan dan bisa beradaptasi dalam hidup new normal dalam menghadapi covid-19, menjalani kehidupan yang efisien dan efektif agar tidak boros dan membangun ide-ide yang kreatif, agar bisa terus survive.

3. Praktek Memberikan bantuan langsung.

Kegiatan PKM ini juga memberikan bantuan langsung kepada masyarakat sekitar berupa barang-barang sembako(seperti beras, minyak sayur, gula, mie dll) agar dapat mengurangi beban ekonomi yang sedang dihadapi oleh masyarakat sebagai bentuk wujud kepedulian social. 


\section{HASIL DAN PEMBAHASAN}

Masyarakat khususnya RW 011 lebih disiplin dalam menerapkan protokol kesehatan dalam mendukung program pemerintah untuk penanggulangan wabah covid-19. Protokol kesehatan seperti memakai masker, sering cuci tangan dan menghindari kerumunan (membatasi jarak fisik) sudah terlihat dilaksanakan dengan disiplin. Monitoring dibantu oleh Karang Taruna untuk memastikan kebiasaan baru ini terus dilaksanakan dengan disiplin tinggi.

Sebagian masyarakat dengan kondisi ekonomi memprihatinkan untuk sementara terbantu secara materi. Hal ini hanya bersifat sementara, oleh karena itu dalam usaha berkesinambungan untuk memberikan bantuan, maka dalam penyuluhan kami juga mengetuk hati masyarakat setempat yang lebih mampu untuk lebih memperhatikan kondisi tetangga yang terkena dampak ekonomi akibat covid-19. Masyarakat khususnya RW 011 lebih bersemangat dalam bertahan menghadapi covid-19. Kepedulian kepada mereka baik secara materi maupun non materi, jelas menambah semangat mereka untuk terus bertahan dan berjuang melawan covid-19.

Bersama Karang Taruna, masyarakat RW 011, Kel. Pengasinan Kota Depok mulai berpikir efisien dan kreatif dalam upaya meminimalisir dampak ekonomi yang diitmbulkan oleh wabah covid-19. Sifat hidup yang tidak boros dan mau menbantu sesama sangat dibutuhkan pada saat pandemi covid-19 ini, kita harus selalu berusaha untuk dapat mencukupi kebutuhan hidup sendiri dahulu dan kemudian membantu orang lain sesuai kemampuan kita.

Ide dan kreativitas dalam menyikapi situasi pandemi covid-19 ini juga memegang peranan penting. Sebagai contoh penerapan pangan mandiri dengan memanfaatkan ruang dan pekarangan di rumah masing-masing, baik itu sayuran, ikan atau ternak ayam skala rumah tangga bisa diterapkan untuk meningkatkan ketahanan pangan keluarga. Jangan menyerah karena covid-19, sehingga tidak melakukan hal-hal yang positif dan produktif. Tetapi kita tetap harus selalu melakukan hal-hal yang positif dan produktif dengan tetap mengikuti pelaksanaan protokol kesehatan dengan baik agar dapat terus beraktifitas dan berkarya. Setiap masalah selalu melahirkan peluang, oleh karena itu berpikir kritis dan kreatif dapat memunculkan ide-ide bisnis baru, yang bisa saja menjadi lahan penghasilan pengganti dari penghasilan yang sudah terlanjur hilang atau berkurang. Mengambil hikmah-hikmah yang positif dari covid-19 ini, kita jadi bisa melihat peluang bisnis yang baru seperti pengadaan masker, hand sanitizer atau sepeda yang sedang banyak digemari, lebih banyak memiliki waktu untuk bersama keluarga dan orang-orang terdekat, bisa lebih banyak waktu untuk belajar bagi Ibu-ibu, seperti belajar membuat kue atau masakan, serta lebih banyak memiliki waktu untuk belajar pelajaran di sekolah/ kampus atau pelajaran agama.

\section{KESIMPULAN DAN SARAN}

\section{Kesimpulan}

Pelaksanaan kegiatan Pengabdian Kepada Masyarakat oleh Lembaga Penelitian dan Pengabdian Masyarakat (LPPM) Universitas Pamulang yang dilakukan oleh dosen-dosen program studi Manajmen telah berjalan dengan lancar dan mendapat sambutan hangat dari tempat pelaksanaan kegiatan ini, yaitu RW 011 Kel. Pengasinan Kota Depok.

Kegiatan PKM ini cukup berhasil meningkatkan kesadaran masyarakat setempat untuk mengikuti protokol kesehatan yang dianjurkan oleh pemerintah agar dapat memutus 
mata rantai penyebaran virus covid-19, membantu kesulitan ekonomi masyarakat, meningkatkan moril masyarakat, dan membantu masyarakat membangun pola pikir agar mengembangkan ide dan kreativitas baru untuk meminimalisir dampak pandemi covid-19 di daerahnya.

Dalam laporan kegiatan ini mungkin banyak kekurangan yang ada, untuk itu kami berharap masukan dan kritikan dalam rangka perbaikan untuk kegiatan-kegiatan pengabdian masyarakat di masa yang akan datang. Semoga kegiatan ini bisa bermanfaat bagi warga RW 011 Kel. Pengasinan Kota Depok dan masyarakat pada umumnya. Akhirnya kami mengucapkan terimakasih kepada seluruh pihak yang telah mendukung kegiatan yang kami laksanakan dan kami mohon maaf apabila dalam laporan ini banyak ditemukan kekurangan.

\section{Saran}

Berdasarkan hasil kegiatan Pengabdian Kepada Masyarakat, maka kami dari Tim Dosen Universitas Pamulang memberikan saran diantaranya sebagai berikut :

1. Mengingat belum adanya kepastian kapan berakhirnya pandemi covid-19 ini, maka dimasa yang akan datang dibutuhkan keberlanjutan dari program-program pemberian motivasi, peningkatan kreativitas dan bantuan sembako serta penciptaan lapangan kerja baru untuk masyarakat yang terkena dampak akibat adanya pandemi covid-19.

2. Adanya kontribusi dari pihak Universitas untuk bisa memberikan fasilitas dalam pelayanan kepada masyarakat dalam bentuk sarana dan prasarana

\section{Ucapan Terimakasih}

Rasa syukur dan suka cita kami haturkan kepada segenap pihak yang telah mensukseskan kegiatan PKM ini dengan judul "Mendayagunakan Peran Karang Taruna dalam Implementasi Bakti Sosial Membantu Mengurangi Beban EKonomi Masyarakat Akibat Wabah Covid-19 di Lingkungan RW 011 Kelurahan Pengasinan, Kota Depok" kepada :

1. Rektor Dr. H. Dayat Hidayat, M.M., Rektor Universitas Pamulang Tangerang Selatan Banten.

2. Dr. Ali Maddinsyah, S.E., M.M., selaku Ketua LPPM Universitas Pamulang Tangerang Selatan -Banten.

3. H. Endang Ruhiyat, S.E., M.M., CSRA, CMA selaku Dekan Fakultas Ekonomi Universitas Pamulang Tangerang Selatan - Banten.

4. Dr. Kasmad, S.E., M.M., selaku Ketua Program Studi Manajemen Universitas Pamulang Tangerang Selatan - Banten.

5. Dr. Udin Ahidin, S.E., M.M., C.M.A, selaku Wakil Ketua Program Studi Manajemen Universitas Pamulang Tangerang Selatan - Banten.

6. Drs. Waluyo Jati, M.M., selaku Sekretaris Program Studi Manajemen Universitas Pamulang Tangerang Selatan - Banten.

7. Bpk. Edi Siswanto selaku Ketua RW 011 Kel. Pengasinan, Kota Depok.

8. Bpk. Novran Yudha Dharmawan selaku Ketua Karang Taruna RW 011 Kel. Pengasinan, Kota Depok.

9. Mahasiswa Universitas Pamulang yang juga ikut berkontribusi terhadap kelancaran kegiatan PKM ini. 


\section{DAFTAR PUSTAKA}

Dariyo, A., \& Esa, D. F. P. U. I. (2004). Memahami psikologi perceraian dalam kehidupan keluarga. Jurnal Psikologi, 2(2), 94-100.

Dumilah, R., Sunarto A., Ahyani., Solihin, D., Maulida H. (2020). Pelatihan Pemanfaatan Media Sosial Untuk Promosi Usaha Atau Bisnis Bagi Siswa. DEDIKASI PKM. Vol. 1. No. 1.

Elder Jr, G. H., Conger, R. D., Foster, E. M., \& Ardelt, M. (1992). Families under economic pressure. Journal of Family issues, 13(1), 5-37.

Fiansyah, A. A. (2019). BAKTI SOSIAL DI BULAN RAMADHAN BERSAMA MASYARAKAT KELURAHAN SURODINAWAN. SKRIPSI Jurusan Pendidikan Pancasila dan Kewarganegaraan-Fakultas Ilmu Sosial UM.

Kerkmann, B. C., Lee, T. R., Lown, J. M., \& Allgood, S. M. (2000). Financial management, financial problems and marital satisfaction among recently married university students. Journal of Financial Counseling and Planning, 11(2), 55.

Leinonen, J. A., Solantaus, T. S., \& Punamäki, R. L. (2002). The specific mediating paths between economic hardship and the quality of parenting. International journal of behavioral development, 26(5), 423-435.

Parrota, J. L., \& Johnson, P. J. (1998). The impact of financial attitudes and knowledge on financial management and satisfaction of recently married individuals. Financial Counseling and Planning,9(2), 59-75.

Raharjo, I. T., Puspitawati, H., \& Krisnatuti, D. (2015). Tekanan ekonomi, manajemen keuangan, dan kesejahteraan pada keluarga muda. Jurnal Ilmu Keluarga \& Konsumen, $8(1), 38-48$.

Robila, M., \& Krishnakumar, A. (2005). Effects of economic pressure on marital conflict in Romania. Journal of Family Psychology, 19(2), 246.

Skogrand, L., Johnson, A. C., Horrocks, A. M., \& DeFrain, J. (2011). Financial management practices of couples with great marriages. Journal of family and economic issues, 32(1), 27-35.

Sunoto, I., \& Nulhakim, A. L. (2017). Mengukur Tingkat Partisipasi Pemuda Dalam Program Karang Taruna dengan Pendekatan Metode Fuzzy Infrence System Mamdani. Simetris: Jurnal Teknik Mesin, Elektro dan Ilmu Komputer, 8(2), 711-720.

Yunus, N. R., \& Rezki, A. (2020). Kebijakan Pemberlakuan Lock Down Sebagai Antisipasi Penyebaran Corona Virus Covid-19. Salam: Jurnal Sosial dan Budaya Syar-i, 7(3), 227238. 